Reseñas

\title{
Cerejido, Marcelino y Fanny-Blanck Cerejido, 2002, La muerte y sus ventajas, SEP, FCE, CONACYT, tercera edición, México.
}

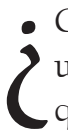
Cuánto conoces acerca de la muerte? Aquí tenemos una pregunta que no muchos se hacen, a pesar de que es una situación presente todo el tiempo. Algunos investigadores, como Marcelino Cerejido y Fanny Blanck-Cerejido, han hecho estudios muy interesantes acerca de la muerte desde el punto de vista biológico, y los datos que se encuentran en su libro La muerte y sus ventajas nos pueden ayudar a entenderla mejor. Me propongo hacer una pequeña síntesis acerca de este libro, que tiene datos muy interesantes y algunas valiosas críticas.

La muerte ha sido una situación muy cotidiana por la que, hasta donde se sabe, todos pasaremos. A pesar de esto, no ha sido muy estudiada. En este trabajo intento mostrar cómo es que nuestro organismo trabaja y cómo la tecnología sigue avanzando para poder conocer acerca de este tema. Comenzaré hablando desde el punto de vista biológico.

En el mundo han existido bacterias unicelulares a las cuales se puede matar de diferentes formas, o al menos nosotros pensamos que así ocurre. Lo que sucede en realidad es que, en lugar de morir, dichas bacterias se dividen en dos. Cuando la célula pertenece a un organismo multicelular, se dice que muere programadamente.

Dentro de cada célula existe una cadena de ADN. Esta cadena consta de cuatro moléculas: Adenina, Tiamina, Citosina y Guanina. Cada cadena de ADN está com- puesta por dos "hebras" enroscadas. Si, por ejemplo, en una hebra hay Adenina, entonces su pareja en la hebra contraria va a ser Tiamina, y si es Citosina, entonces su pareja va a ser Guanina. Entonces la cadena quedaría:

\section{ATCAAGTACCT GAT TGCCAAATGC}

TAGT TCATGGACT AACGGTT TACG

Cuando una célula se divide, su núcleo y su cadena de ADNlo hacen también, por lo que cada nueva célula tiene que crear la parte faltante de la cadena dependiendo de la información recibida.

De la cadena de ADN se crea otra, pero mucho más pequeña, que en lugar de tener la molécula Tiamina, tiene una " $U$ " (en el texto no se menciona el nombre de esta molécula). Estas cadenas, llamadas de ARN, son mandadas a los ribosomas, los cuales se encargan de decodificar este mensaje. Ya leído el mensaje, se acomodan aminoácidos según se requiera y se forma una hebra llamada péptido. Al segmento que especificó la secuencia de péptidos se llama gene, y al conjunto de genes se les llama genoma.

A pesar de la variación que pueda haber de los genes, se necesita seguir ciertas órdenes para obtener lo que deseamos, ya que no serviría de nada crear alguna parte de un organismo si no hay nada que lo controle, no sirve para algo en específico o está incompleto. Estas órdenes 
pueden cambiar, según factores como la edad, ya que en ciertas edades necesitamos ciertas cosas y en otras no.

Para obtener lo que deseamos se necesita hacer una diferenciación, la de un proceso por el que las células leen la información genética y la transforman en lo que se busca. Se ha creado una hipótesis acerca de la muerte celular programada, o apoptosis, en la cual las células se "suicidan" y dejan que otras las devoren para el bien del organismo. A veces las células tienen la orden de realizar algún trabajo y después suicidarse, pero en el momento de estar haciendo dicho trabajo, reciben la orden de no suicidarse; por otro lado, si en algún caso la célula no cumple con su trabajo, la nueva orden no se recibe y, por tanto, se eliminan las células deficientes.

En ocasiones comienzan a existir nuevos genes que son desechados, si no conllevan algún beneficio para el organismo. Es extraño que el gen de la muerte se haya conservado ya que, al parecer, el organismo no obtiene ningún beneficio de él.

Las células obedecen órdenes, por lo que en la niñez el organismo elimina los errores provocados por las células deficientes. Se puede considerar esta orden como una ventaja porque dichas células se pueden reemplazar por otras eficientes.

Se ha podido encontrar información acerca de estas células suicidas, ya que los suicidios ocurren de forma regular y con ciertos "síntomas"; además existe la presencia de agentes externos e internos que ayudan a la eliminación de la célula y de todo rastro de ella.

Una de las ventajas de la muerte celular es la constante regeneración de las células, que evita el envejecimiento celular y el crecimiento de tumores. Existen genes llamados ced, que deciden si alguna célula debe morir o no. Para dar continuidad a la existencia de las células existen las llamadas troncales, que se encargan de permanecer mucho tiempo en el organismo y dividirse en dos, ordenando a una de sus "hijas" que se siga dividiendo, mientras que la otra se queda guardada en el organismo durante mucho tiempo, hasta que se le necesite; de esta forma, el organismo siempre va a tener reservas.
La muerte de las células no ocurre porque las células caduquen, ya que se renuevan constantemente y, en muchos casos, los organismos muertos aún tienen células vivas. Por esto los seres vivos no mueren por vejez, sino por enfermedades. El hecho de que algunos animales vivan mucho y otros poco no es por alguna situación celular, sino por el tipo de metabolismo de cada animal y por estrategia evolutiva. Cada organismo tiene su longevidad según lo vulnerable que sea, al igual que su reproducción, ya que puede haber animales que vivan mucho y sólo tengan una cría, y otros que vivan muy poco y se reproduzcan mil veces más.

Una de las ventajas de la muerte programada es que se ha logrado la evolución de los diferentes organismos, ya que al morir éstos, se fueron creando células mejor adaptadas al medio ambiente. Gracias a la muerte programada los seres humanos estamos aquí tal como nos conocemos.

Al parecer, la naturaleza ha creado a los seres vivos para reproducirse y evolucionar, ya que muchos de los seres vivos mueren al final de la reproducción. Existen varias hipótesis acerca de cómo un organismo multicelular muere, pero no significa que sólo una sea válida, sino que todas tienen un grado de validez y quizá, al lograr unir todas las hipótesis, se logre crear una sola.

Los organismos sobreviven, ya que reparan los órganos creando más células, pero en general lo hacen con los que más tienden a dañarse. Esto tiene mucho que ver con la edad del organismo, ya que la eficiencia será diferente por causa del envejecimiento del organismo en general y del centro de mando, y también de su capacidad para regenerar células.

La muerte es causada por muchos factores, pero esto no significa que la extinción sea uno de ellos. Los humanos se las han arreglado para evitar lo más posible la muerte. Por esto se ha creado una sobrepoblación. Las causas de muerte pueden ser externas y variadas. Los seres humanos somos los únicos, durante la evolución, que nos hemos ayudado y hemos salvado a los genes imperfectos. 
Existen varias formas para alargar la vida, pero no ha habido ninguna que nos ayude a ser inmortales. A pesar de haber avanzado mucho en los conocimientos y descubrimientos, aún no se puede evitar morir. Por eso realizamos actividades para dar sentido a la vida. El seguir viviendo depende de la salud y de la voluntad.

El temor a la muerte existe; conforme pasa el tiempo se han creado formas culturales de representarla y hacerle frente; sin embargo, los avances tecnológicos y de la ciencia las han descartado, dejándonos sin saber nada en concreto y por eso le tememos a lo desconocido.

La concepción de la muerte varía con la edad, cuando somos pequeños la tomamos como "irnos" o "partir", pero conforme vamos creciendo, la muerte se convierte en algo mucho más cercano, lo que provoca que, cuando somos adultos, la sentimos más cerca. Por causa de esto, los humanos hemos creado varios mitos y religiones para sentirnos seguros con respecto a la muerte, ya sea pensando que hay una vida después, que nuestras almas se irán a un paraíso, a un infierno según nuestros actos, con el simple hecho de que las personas aún vivas nos recuerden.

Por miedo a la muerte, y quizás a lo desconocido, tratamos de aprovechar la vida lo mejor posible. Hay personas que se han preguntado a qué le temen más, si a la vida o a la muerte: a lo que yo más le temo es a la muerte, porque no sé cómo se siente, y por ser desconocido me asusta. Sé, en general, cómo es la vida y lo que puede suceder en ella, además conozco las soluciones para los problemas cotidianos, pero si encuentro alguna razón lo suficientemente buena como para morir, será porque no pude hallar otra solución. Al menos sé que para la vida hay una salida: la muerte; ipero existe alguna salida para la muerte?

Viridiana Escalona Gutiérrez Estudiante de Licenciatura en Química Universidad Autónoma Metropolitana-Xochimilco 